\title{
Rwanda Defence Force Socio-Economic Activities And Community Welfare Of Citizens Of Rwanda: The Case Of Gasabo District
}

\author{
By Author: Manzi Isaac \\ Co-author: Dr Safari Ernest \\ Department of international relations, Mount Kenya University \\ DOI: 10.29322/IJSRP.11.08.2021.p11619 \\ http://dx.doi.org/10.29322/IJSRP.11.08.2021.p11619
}

\begin{abstract}
This study investigated the contributions of Rwanda Defense Forces (RDF) of socio-economic activities and community welfare of citizens of Rwanda the case study of Gasabo district. The study applied both qualitative and quantitative methods of data collection and analysis using questionnaires and interviews. Data was collected from a total of 379 general RDF field officers and 384 community members using survey questionnaires and 5 high rank RDF officers using interview guide. The study findings revealed that the significant socio-economic activities conducted by RDF include; construction of classrooms (mean=2.5736),
\end{abstract} construction/rehabilitation of houses for vulnerable people (mean $=2.6138)$, houses constructed for genocide survivors (mean=2.6882), distribution of electricity (mean=2.6260), agricultural and environmental protection $($ mean=2.6756) and construction of Health, milk and potato collection centres (mean=2.7202). The RDF significantly contributed to welfare of Rwandan citizens through improvement in learning conditions and environment $($ mean=3.0289), transport of goods and movement of people (mean=2.8813), health (mean=2.8097), household food security $($ mean $=2.7078)$, overcrowding in classrooms (mean=2.7002), incidence of pests and diseases in both crops and livestock (mean $=2.6956)$, antenatal care services $($ mean=2.6841), shelter and state of residence (mean=2.6514), peace and security (mean=2.6438), clean and efficient energy supply in households for lighting (mean=2.6082). The major challenges faced by RDF are; limited financial resources (mean=3.5736), unsustainable human resource bases mean=2.9138 and lack of effective performance oversight $($ mean $=2.6260)$, inefficient evaluation programmes (mean=2.6756). Linear regression model indicated that the RDF has contributed significantly to welfare of Gasabo district community members $(\mathrm{F}=13.855, \mathrm{df}=13$ and $P=0.000)$. The study concluded that the RDF has undertaken various socio-economic activities that have improved the welfare of Rwandan citizens. The study recommended for a budget increment for socioeconomic welfare. I hereby declare that this research is my own work and to the best of my knowledge it contains no materials previously published or written by a notherperson

Index Terms- Rwanda Defence forces (RDF), Socio-economic, Contributions, Welfare and Gasabo district

\section{INTRODUCTION}

A ccording to Gervais, (2013) study, it is negated that not only has Rwanda Defense forces (RDF) engaged in protection of people and their property but has also engaged socio-economic activities aimed at improving the welfare of Rwandan people (Gervais, 2013). RDF derives its mandate from article 10 of the country's law and the law provides among its mandates to participate in humanitarian activities in case of disaster, contribute to development and participate in peace keeping missions (Gervais, 2013). Since the 1994 genocide, Rwanda has encountered challenges in its efforts to provide services for genocide survivors and vulnerable households. As Rwanda emerged from post-genocide recovery, the main agenda was restoring human dignity and sustaining it through future generations (Douglin et al., 2015). Lunatic

Despite RDFs socio-economic activities undertaken, their contributions to people's welfare in Gasabo district have not been acknowledged in academic literature for improvement and policy guidance. The lack of knowledge on the contributions or failures of RDF socio-economic activities on community member's welfare can lead to recurrent socio-economic problems that undermine development and welfare. Studies (Chossudovsky, 2016; Douglin et al., 2015; ) have indicated that since 1994 when the country had experienced mass loss of lives, households and localities that experienced more intense conflict are lagging behind in terms of standards of living whereby households have no decent shelter, high disease incidence since the health infrastructure was destroyed during the conflict and other socio-economic problems (Strachan, 2017).

Also during genocide, the country's social and physical infrastructure was decimated, trade links were ruptured, businesses and agricultural assets dwindled, and institutions of governance required rebuilding and this also called the need for participation of different departments of today's government to achieve desired country's development concerns (Holmes \& Holmes, 2014). The country has made different strides in dealing with socio-economic challenges through different activities like distribution of cows, agriculture modernization, and social infrastructure improvements and among others and the RDF has been at the forefront of all these activities (Holmes \& Holmes, 2014). Hence the need to investigate the contributions of Rwanda 
Defense Forces (RDF) of socio-economic activities and community welfare of citizens of Rwanda with a case study of Gasabo district to improve on the public awareness and make recommendations for further improvement

\section{LITERATURE REVIEW}

\section{Socio-economic activities}

Runfola et al., (2020) indicated that social activities like afforestation, tree planting and forest conservation were the major socio-economic activities carried out among people around forest areas in Uganda and this accelerated their income through tourism and increase in livelihood products however in Ghana, unsustainable agricultural practices, indispensability of agrochemicals were the socio-economic activities practiced by citizens in Ghana Ametefe, (2016) however, these activities were reducing the welfare of citizens since they were unsustainable and could lead to loss of household income and assets in a long run. Still in comparison there is no study indicating in literature the predominant socio-economic activities. Construction of feeder roads, markets and building of bridges were the community socio-economic activities identified within Ethiopian local communities (Paradowska, 2017).

In Nigeria, farming, trade, fishing and trading were found to be the major socio-economic activities in south east Nigeria (Ifeanyi-obi, 2014). In the EU, the socio-economic activities in all sectors of the economy were as banking, insurance, agriculture, craft, various commercial services, and health and social service activities (Tremblay, 2011). In Cambodia, the socio-economic activities were; agriculture, forestry and fishing, mining, manufacturing, provision of educational services a mong others (Conner, 2014). The other socio-economic activities were; logging, agroforestry, agriculture and shifting cultivation (Strachan, 2017). In summary the socio-economic activities reviewed in literature are seen to be double sided as they lead to both negative and positive outcomes according to the way they are practiced. Furthermore, the studies reviewed have been conducted in both developed and developing countries such as the European union countries, African countries such as Ethiopia and Uganda leaving Rwanda out of the context, leaving a knowledge gap hence this study.

Contributions of socio-economic activities to peoples' welfare According to Lwelamira, (2015) in Dodoma Tanzania, results indicated that grape farming contributed to more than one third $(35.6 \%)$ of total household income, food security and plays an important role in household welfare. Grape farmers had higher household consumption expenditure than non-grape farmers. In Nepal community engagement in forestry activities enabled capital formation, governance reform and community empowerment, and social change (Pinder \& Wood, 2012) and (Hussain, 2015) study results indicated that social forestry contributes to over 60 percent of the annual fuel wood consumption and growth in household income. Also Community Forestry Project in Dolakha and Ramechhap districts is gearing towards gender sensitive, poverty-oriented and equity-focused outcomes and contributing to rural social transformation (Upreti, 2017), community forestry related activities in the study area a re gearing towards balanced social, economic and ecological benefits (Upreti, 2017)

According to Karaburun-sazani, (2012) it was revealed that in any community, when the individuals will be educated, they will be able to make use of their knowledge, information, skills and abilities to promote developments, changes and wellbeing of the community. Studies have indicated that rural roads have contributed to access to market for agricultural produce thereby increasing household income hence welfare. People have invested highly a long highways as indicate by the study in Croatia (Skuflic, 2016). A three-year randomized, controlled trial in rural Nicaragua found that a footbridge resulted in a 30 percent increase in household income and a 56 percent increase in a gricultural yields of staple corn crops. The study also found that bridges increased investments back into the community, represented by a 69 percent increase in spending on agricultural goods like fertilizers and pesticides (Chang, 2014).

In summary here, since genocide it has been shown that the remaining population underwent series of socio-economic challenges due to declines in both social and economic spheres of life that spurred the RDF that was formed after FAR to restore the socio-economic environment. However the socio-economic contributions of social and economic to peoples welfare reviewed have been seen to appear in countries of which Rwanda is out which leaves a research gap in Rwandan context to be filled hence the study.

\section{Challenges faced by socio-economic services providers}

Limited funds and poor attitudes beneficiaries to change significantly affects affected socio-economic development activities (Dhludhlu \& Lombard, 2017), challenging certain a spects of current social and policy contexts (Saeed et al., 2016). Mbah \& Mgbenka, (2014), research showed clearly that the funding required for ensuring the sustainability of the organisations is insufficient, and that the human resources are unstable. Many social workers in communities have experienced the negative consequences of poor governance, corruption and mismanagement of revenues (Schüler et al., 2016). With this legacy, the socioeconomic sector currently faces widespread mistrust and rejection from communities in many parts of the world; and organizations must make concerted efforts to ga in a social license to operate (Schüler et al., 2016).

Political market imperfections, policy incoherence, lack of effective performance oversight and Collective action challen ges were the challenges faced by government bodies in service delivery (Wild et al., 2012). OECD countries have faced the these challenges; the lack of resources to conduct evaluations; the lack of pre-reform mea sures of performance; the complexities in measuring efficiency in the public sector; and the problem of isolating the effects of specific institutional reforms on efficiency from other external influences during service delivery (Curristine et al., 2017). The Australian government has faced market and community service organisation failure including the failures associated with government structures, market drivers, and the resource constraints of the community service sector as challenges impeding social economic transformations (Billis \& Glennerster, 2012). The challenges manifested in this literature are general in nature and are not specific to any country hence a research gap 


\section{RESEARCH DESIGN AND METHODOLOGY}

Research deployed a cross-sectional case study plan. It was conducted by use of survey questionnaires and interviews. Therefore, both numerical and thematic data was got. In short, research deployed mixed research methods which is defined as an evolving method of investigation that uses methodicalmixing of measureable and thematic information inside one scientific research and these methods aid triangulation of results that helps in strengthening research finding. Merging figures with thematic methods avoids too much reliance on the previous and captures important views and familiarities. The weakness in one research method can easily be got rid of by the other method and on an extra thinking level, diversified approaches of research

\section{Conceptual Framework}

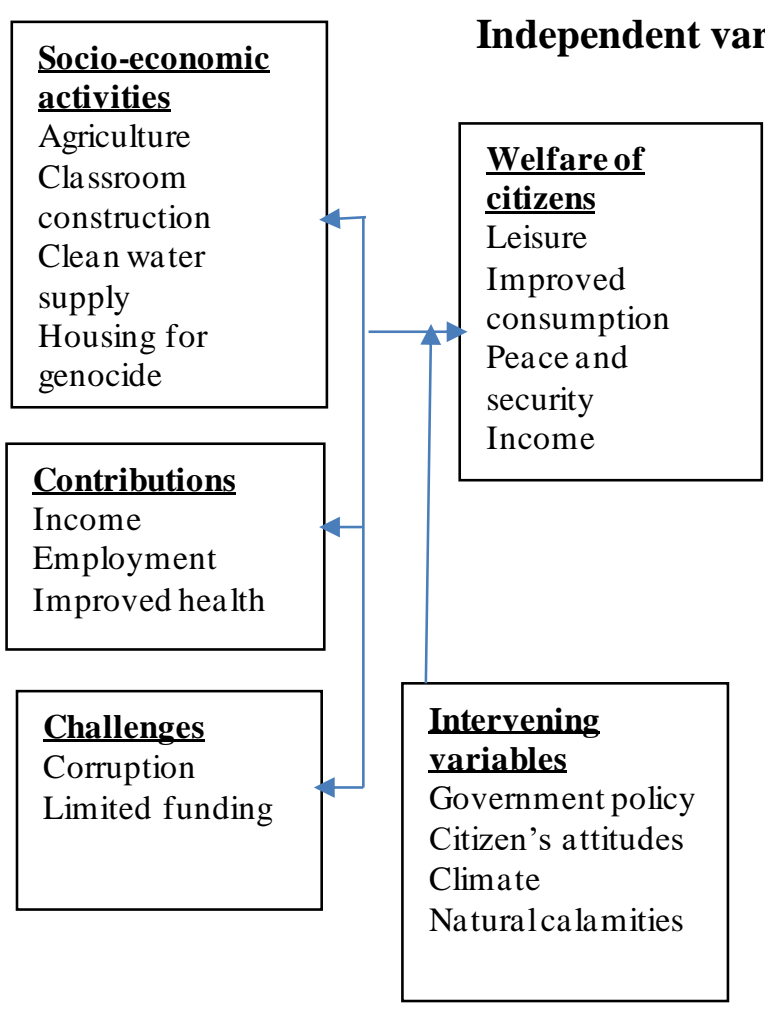

Figure 1 Conceptual Framework

Source: (Gervais, 2013) with modification

As indicated in figure 1 the independent variables include; the socio-economic activities (agriculture, shelter construction) since some studies such as (Matei \& Dorobantu, 2015, 2019) have indicated that social economy contributes to developing a social cohesion-generating economy forming new mentalities for the local social-economic environment. In Nigeria, (Adelakun \& Bussa, 2015) indicated that the socio-economic activities are; farming (58.2\%), hunting (21.8\%), lumbering (10.9\%) and trading $(5.5 \%)$ purposely to meet social and economic needs.

The contributions of socio-economic activities to the welfare of citizens (income, employment, etc) can either be mediated by some extraneous variables such as government policy for example in South Korea, there was interconnectedness syndicates standards, letting study from both the inductive and deductive viewpoints, and so enabling investigators to associate philosophy invention and proposition testing in one research study (Malina et al., 2011; Regnault et al., 2018)

Population, sampling, sampling technique and data collection

The study population composed of RDF officers of higher ranks, general RDF field officers and local community members. Simple random sampling was used to select the general field officers and local community members while purposive sampling was used to selected high ranking RDF officers. Data was collected from a total of 379 general RDF field officers and 384 community members using survey questionnaires and 5 high rank RDF officers using interviews.

\section{Dependent variable}

between government policy and service content, which can improve leisure activities, hobbies, and self-development and challenges faced while delivering socio-economic activities. Also in Uganda, (Khisa, 2015) indicated that political uncertainties have obstruction socio-economic transformation

The involvement in social economic activities is determined by willingness and the nature of attitudes of citizens in a given country and therefore the nature of the effect of socio economic activities citizens act through citizens attitudes (Munoz et al., 2019). Some people may not be willing to work and this implies that their welfare situation may be hampered in a long run. All these categories through the extraneous variables affect the dependent variable either negatively or positively as revealed by Lwelamira, (2015) who found that households which were engaged in grape farming had increased expenditure on 
consumption hence improved welfare. However the nature of the effect of the independent variables on the dependent variable can be either improved or reduced by the extraneous variable like government policy, citizens attitudes, climate or natural disasters (Dhludhlu \& Lombard, 2017).

\section{DATA ANALYSIS AND RESULTS}

SPSS was used as tool for quantitative data a nalysis while thematic analysis was used for qualitative data. Descriptive statistics including mean and standard deviations were used and linear regression model was used to determine the overall contributions of RDF to socio-economic activities and peoples welfare.

\section{RESULTS AND DISCUSSION}

Socio-Economic Activities of Rwanda Defense Forces (RDF) in Gasabo District Communities

Table 1 Socio-Economic Activities of Rwanda Defense Forces (RDF) in Gasabo District Communities

\begin{tabular}{lllll}
\hline Statement & Mean & SD & $\chi^{2}$, df & P-value \\
\hline Construction of classrooms & 2.5736 & 1.12467 & $523.64,4$ & 0.000 \\
Construction/rehabilitation of houses for vulnerable people & 2.6138 & 1.25383 & $54.69,4$ & 0.000 \\
Clean water distribution & 2.4477 & 1.18324 & $1.17,4$ & 0.793 \\
Houses constructed for genocide survivors & 2.6882 & 1.20432 & $1.68,4$ & 0.000 \\
Distribution of electricity & 2.6260 & 1.25272 & $623.68,4$ & 0.000 \\
Agricultural and environmental protection & 2.6756 & 1.22138 & 57.17 .4 & 0.013 \\
Construction of Health, milk and potato collection centres & 2.7202 & 1.24068 & $456.465,4$ & 0.000 \\
\hline
\end{tabular}

Scale mean $<2.5$ insignificant and mean $\geq 2.5$ significant and $P<0.05$ is significant, $p>0.05$ insignificant

Results in table 1 revealed that the RDF significantly constructed classrooms in Gasabo district and this is in collaboration with information presented in the RDF report (RDF, 2018) where it was revealed that 12 storied classrooms were constructed at groupe scolaire Kagugu Gasabo district. In total during the financial year 2017/2018, 203 classrooms were reported to have been constructed around the country in a bid to support the ministry of education in improving education for all across the country. The results are however in contradiction with Barrett et al., (2015) who revealed that classroom design is important in learning achievements of students. Further in collaboration with Stadler-altmann, (2020), it was revealed that the RDF with other partners from the ministry of education have been constructing storied classrooms in a bid to save land for other purposes, in short they have promoted vertical expansion rather than horizontal expansion. Research also shows that despite the COVID-19 pandemic bottlenecks, the RDF was able to continue offering socio-economic support to citizens for example Tabagwe Mixed Secondary was constructed and completed during the pandemic times of 2020

Significant results on the provision of electricity are in contradiction with (Martin \& Kruger, 2020) findings who reported that the major socio-economic activities carried out by the UPDF in Uganda is protection people and their property though the results collaborate with data presented in in the RDF, 2018 socio-economic activity that revealed that Nyabarongo hydro power plant is one of the power station in Rwanda which was completed in 2014 by the RDF (RDF, 2018). This power station produces 28 megawatts and is believed to be the largest power station so far in the Rwanda. Though this dam power station was constructed by foreign companies that is Angelique International Limited \& Bharat Heavy Electricals
Limited of India, the distribution and transmission ha s been done by the RDF engineers which collaborates with the study findings. The information in the book indicates that the RDF is socially and economically transforming Rwanda. Significant progress has been by RDF in installation of electricity grids both within Kigali and in up county districts and it has been revealed that electricity contributes to $2 \%$ on the country's GDP. Since the RDF has been striving to eradicate poverty and studies have indicated that electricity access correlates with economic development, the study findings collaborates with (Kanagawa, Makoto, 2018; Stern et al., 2017) who indicated that for any socio-economic activity package, energy provision should be included area

Results further revealed that the RDF has significantly provided clean water to the citizens which collaborates with the RDF work book 2018 that reported that about 12 Water and sanitation projects have been undertaken in all districts of Rwanda since 2009 that have left people with enough access to water and sanitation facilitation like water flushing toilets among others and this was in collaboration as reported in (Martin \& Kruger, 2020) who revealed that the RDF has constructed different clean water sources including boreholes and taps to enable access to clean water to citizens. It was estimated that these projects costed about 6,479,563,064 FRW. Boreholes have been constructed in different parts of the country to ease access to clean water (RDF, 2018).

The results further indicated that protection of environment has been done by the RDF and this agrees with (Nkundabose et al., 2020) who revealed that Rwanda enhances developmental projects to be viable and environmentally friendly . Environmental protection is a crucial factor for flourishing population and the RDF has done all it requires to modernize a griculture and protect the environment. The RDF has conducted 
activities in these sectors worth 19.89 billion FRW which include; soil erosion control, distribution of livestock and crop production. Activities relating to agriculture and environmental protection have covered 25418 hectares of land, 3525 cows have been distributed under one cow per family initiative (Girinka). The RDF has been at the forefront of establishing terraces (amateerasi) not only to avert soil erosion but also to improve soil productivity. About 3441 hectares have been planted with trees to increase environmental protection and river bank protection has been done with bamboo a long Nyabarongo River. Crop and vegetable production has covered 1701.9 hectares, vegetables such as dodo, egg plants, hot pepper among others have been distributed and planted by the RDF. Varying hectares of land have been cultivated with different types of crops such a s potatoes, wheat, bush beans, and wheat to mention but a few. Other successful activities undertaken by the RDF include; continued eradication of the fall army worm, rejuvenation of banana plantation and eradication of banana weevil. Also around 2548 hectares of coffee and tea have been planted and fert ilizers applied. But all these disagree with (UNDP, 2018) report that revealed that though a country's welfare is measured by consumption rate of citizens but people in Rwanda still die of hunger meaning that the RDF has not addressed hunger through a griculture
It was also indicated that the RDF significantly provided health services as one of the socio-economic activities undertaken as this is in collaboration with (Saeed et al., 2016) who opined that health sector is essential to a stable, functioning economy. The study results contradict with information report in the (RDF, 2018) booklet profiling all the socio-economic activities undertaken by the RDF. In the same booklet, it is evident that the RDF outreach programme among other things focused on proving health services to community members. Since 2009, 438,371 citizens had benefited from the medical services provided by the RDF. The areas covered by the RDF medical services include; Gynecology, Ear nose and throat (ENT), Circumcision (SMC), Dental services, Obstetrics and among others. The entire health services that were provided since 2018 have Costed 147M FRW but the real market value was $1 \mathrm{bnFRW}$ and the government was saved of $853 \mathrm{M}$ FRW. The RDF has built medical centres, child development centres where citizens learn balanced diet and get medical checkups. The RDF outreach programme has managed to construct 6 hospitals and health centers, 114 rooms for health counselors.

\section{Contributions of Rwanda defense forces (RDF) activities to} welfare of citizens of Rwanda

Table 2 Contributions of Rwanda defense forces (RDF) activities to welfare of citizens of Rwanda

\begin{tabular}{|c|c|c|c|c|}
\hline Statement & Mean & SD & $\chi^{2}, \mathbf{d f}$ & P-value \\
\hline $\begin{array}{l}\text { Learning conditions and environment has been improved } \\
\text { tremendously }\end{array}$ & 3.0289 & 1.22467 & $37.773,4$ & 0.000 \\
\hline Transport of goods and movement of people was made easy & 2.8813 & 1.23383 & $29.769,4$ & 0.000 \\
\hline Most diseases controlled hence improve health & 2.8097 & 1.28324 & $14.039,4$ & 0.007 \\
\hline Improved household food security & 2.7078 & 1.30432 & $34.622,4$ & 0.000 \\
\hline Overcrowding in classrooms a verted & 2.7002 & 1.29272 & $27.162,4$ & 0.000 \\
\hline Reduced the incidence of pests and diseases in both crops and livestock & 2.6956 & 1.28138 & $25.357,4$ & 0.000 \\
\hline Malnutrition among children mitigated & 2.6822 & 1.28068 & $7.890,4$ & 0.981 \\
\hline Antenatalcare services to pregnant mothers escalated & 2.6841 & 1.28184 & $23.456,4$ & 0.034 \\
\hline $\begin{array}{l}\text { Improved household income through encouraging the growing of cash } \\
\text { crops }\end{array}$ & 2.6734 & 1.28138 & $9.123,4$ & 0.125 \\
\hline $\begin{array}{l}\text { Prevented flooding and soil erosion of crops and household by creating } \\
\text { terraces }\end{array}$ & 2.6560 & 1.26468 & $6.844,4$ & 0.144 \\
\hline Improved shelter and state of residence & 2.6514 & 1.32215 & $36.034,4$ & 0.012 \\
\hline Improved peace and security & 2.6438 & 1.23968 & $31.301,4$ & 0.000 \\
\hline Clean and efficient energy supply in households for lighting & 2.6082 & 1.28380 & $27.678,4$ & 0.002 \\
\hline Easy access to market for a gric. Products due to constructed roads & 2.5236 & 1.28138 & $11.234,4$ & 0.078 \\
\hline Illiteracy and ignorance a verted through free education & 2.4977 & 1.27622 & $5.671,4$ & 0.451 \\
\hline
\end{tabular}

\section{Scale mean $<2.5$ insignificant and mean $\geq 2.5$ significant and $P<0.05$ is significant, $p>0.05$}

Results in Table 2 revealed that the RDF has improved the learning conditions and environment and this is in collaboration with findings in the RDF, 2018 report which indicates that the RDF has constructed and completed 1380 classrooms with associated 1126 toilets, (Williams, 2018) also revealed that in order to address development concerns there should be too much of the investment in educational infrastructure. Also 168 houses for teachers have been constructed and this improved the overall welfare of education sector stakeholders. Results further revealed that the RDF has made the movement of goods and people and 
this is in agreement with findings of the RDF, 2018 book on social economic activities of the RDF that revealed that $385.6 \mathrm{~km}$ of feeder roads have been constructed and 1 modern market has been constructed which has improved income of rural farms since they can easily transport their agricultural products to a known and modern market constructed by the RDF. The RDF was also believed to have controlled diseases and this tallies with reported results in the RDF 2018 socio-economic activity booklet that indicated that the RDF has been in health care since 2009 and since then 438,371 patients have been treated by the year 2018. This was achieved through the RDF citizen outreach programme (COP) which among its core objectives was to provide health services to the citizens. Among the diseases treated under this programme included cancer of different parts of the body, malnutrition related diseases among the children such as kwashiorkor and diseases of the ear, nose and throat (ENT). These results on health are in contradiction with (Sayinzoga \& Bijlmakers, 2016) who revealed that health services covering ENT a few due to their complexity and the RDF has few medicalspecialists.

The RDF was also reported to have contributed to enhanced household food security and this this is in agreement with the reported large numbers of hectares cultivated with wild beans, cassava, banana, pineapples and wheat and this is in agreement with (RDF, 2018) book on Rwanda national transformation. Other vegetable crops have been planted such a s beetroot, egg plants, and cucumber among others. The application of fertilizers and irrigation system are symbols for the continuous promotion of food security among the RDF. Terra ces constructed in gardens also evidences food security strategy, distribution of cattle which are high mil yielding was also astride to enhance food security. One of the indicators of improved welfare is increased consumption in household enhanced by enough food as indicated in (Adonu et al., 2020; Riches, 2016; Semazzi \& Kakungulu, 2020) who revealed that food aid enhanced welfare in the recipient country though it reduced welfare in the donor countries so it is a moral responsibility to reduce poverty in the recipient. RDF has also reduced overcrowding a statement which agrees with Jean Baptist Habanabashaka, who reported that during the RDF COP, RDF in collaboration with various government institutions started effort to address a challenge of overcrowding in classrooms, he added that the construction of classrooms is timely as students had hit 80 per classroom in most of government schools and this had made most of the schools to resort to morning and evening classes.

$\mathrm{RDF}$ has also reduced the incidence of pests and this is also in agreement with the RDF socio-economic book of 2018 that indicated that the fall army worm, banana weevil, cassava mosaic virus have been eradicated and another report from Rwanda nationalcontingency plan for a nimaland plant disea ses revea led that RDF, have worked together the ministry of agriculture prevent the introduction of highly Pathogenic avian influenza (HPAI) into Rwanda and ensure preparedness in the event of an outbreak. The RAB has made stocked additional vaccines, enhancing surveillance and diagnostic activities, increasing smuggling intervention and trade compliance activities, conducting investigations, carrying out research and development, administering planning and preparedness training, and conducting various activities internationally to combat the virus. Though the RDF has revealed the practice of terraces and planting of bamboo trees along river banks as indicated in the RDF 2018 book on socio-economic activities, the results contract with this. RDF report indicated that the RDF has been at the forefront of establishing radical terraces to a vert soil erosion and also increase productivity. Rwanda being a hilly area in general, has been experiencing high rates of soil erosion which in turn lowered soil productivity in terms of agriculture and therefore the $\mathrm{RDF}$ intervention to create terraces to avert this challenge was timely but no significant impacts so far.

Challenges Faced By Rwanda Defense Forces (RDF) In Struggle to Execute Their Social Economic Activities in Gasabo District

In the struggle to advance socio-economic activities of the RDF, there are various challenges faced by the stakeholders and table 3 puts them forward.

Table 3 Challenges Faced By Rwanda Defense Forces (RDF) In Struggle to Execute Their Social Economic Activities in Gasabo District

\begin{tabular}{lllll}
\hline Problem & Mean & SD & $\chi^{2}$, df & P-value \\
\hline Limited financial resources & 3.5736 & 1.12467 & $423.68,4$ & 0.000 \\
Unsustainable human resource bases & 2.9138 & 1.25383 & $44.66,4$ & 0.000 \\
Unfavorable government policy & 2.1477 & 1.18324 & $11.11,4$ & 0.793 \\
Corruption in RDF staff and localleaders & 2.2882 & 1.20432 & $12.66,4$ & 0.100 \\
Lack of effective performance oversight & 2.6260 & 1.25272 & $723.638,4$ & 0.000 \\
Inefficient monitoring and evaluation programmes & 2.6756 & 1.22138 & 27.171 & 0.013 \\
Negative attitudes to change among community members & 2.4202 & 1.24068 & $256.465,4$ & 0.203 \\
\hline
\end{tabular}

Scale mean $<2.5$ insignificant and mean $\geq 2.5$ significant and $P<0.05$ is significant, $p>0.05$

Major challenges faced by RDF are; limited financial resources (mean=3.5736), unsustainable human resource bases mean $=2.9138$ and lack of effective performance oversight (mean $=2.6260)$, inefficient evaluation programmes (mean=2.6756). In contradiction with Kabananukye, (2006), it was revealed that population explosion is the major challenge for socio-economic transformation, also in disagreement with Wierzbicki, (2014) the findings that conflicts between 
corporatization and governance; the conflict between direct and indirect limits to freedom are the major impediments to socioeconomic transformation

Limitations and future research

The residents of Gasabo district were not willing to disclose out some of the information to the researcher due its sensitivity in nature. However this problem was solved by assuring them that the study is purely for academic purposes. Funds were limited to cover all costs in the course of carrying out this study. These costs included; transport, communication and stationery. However this was solved by seeking financial assistance from relatives and friends. Time constraints due to the need to balance work and studies however this was solved by asking off days from work. Further research should be done to a ssess the attitudes and perception of local comm unity members of Gasabo district about working with the RDF in pursuing their socio-economic activities and also investigating how the saved money has been utilized to improve the welfare of citizens.

\section{Managerialimplications}

Government should increase the budget that goes to RDF socio-economic support projects so as to improve their efficiency and coverage and this is drawn from the findings that have indicated that one of the major challenges experienced by the $\mathrm{RDF}$ is limited financial resources. Performance oversight mechanisms should be developed and implemented to track the progress and performance of all projects undertaken by the RDF. This is always aimed to identifying the challenges unknown that could be hampering the achievements set at the beginning of each project. Monitoring and evaluation programmes should be instituted throughout the whole projects cycle to weed out all undesirable acts that would least to failure of socio-economic projects. This helps to achieve overall welfare of the citizens and Ga sabo district community members should be sensitized on how to collaborate with the RDF during their activities so as to achieve overall welfare derived from these socio-economic activities

\section{CONCLUSION}

The study concluded that the RDF has undertaken various socio-economic activities that have improved the welfare of Rwandan citizens

\section{REFERENCES}

[1] Adelakun, K. M., \& Bussa, N. (2015). Socio Economic Activities of Ru ral Community and their Perception on Conservation in Okomu National Park Socio Economic Activities of Rural Community and their Perception on Conservation in Okomu National Park. International Journal of DevelopmentStrategies in Humanities and Social Sciences, 5(1), 66-73.

[2] Adonu, D., Opuni, Y. A., \& Dorkenoo, C. B. (2020). Implications of COVID-19 on Human Resource Practices : A Case of the Ghanaian Formal Sector. 8(4), 209-214. https://doi.org/10.11648/j.jhrm.201200804.11

[3] Ametefe, R. (2016). Impacts of socio-economic activities of com mun ities on water resource management in Songor bioshpere reserve. The Division of Ecological Sciences UNESCO (MAB) Young Scientist Research Award Scheme, 17(1), 49-56.

[4] Barrett, P., Davies, F., Zhang, Y., \& Barrett, L. (2015). The impact of classroom design on pupils' learning: Final results of a holistic, multi- level analysis. Building and Environment, 89, 118-133. https://doi.org/10.1016/j.buildenv.2015.02.013

[5] Chang, S. (2014). Values of Bridge in the Formation of Cities Values of Bridge in the Formation of Cities. IABSE Symposium Report, 1 (1), 23 24. https://doi.org/10.2749/222137809796089142

[6] Chossudovsky, M. (2016). Economic Genocide in Rwanda: Economic and Political Weekly Economic Genocide in Rwanda. Economic and Political Weekly, 31(15), 938-941.

[7] Conner, N. (2014). Socio-Economic Dimensions of Human Dependence on Nature. People in Nature, 56(7), 44-51.

[8] Curristine, T., Lonti,Z., \& Joumard, I. (2017). Improving Public Sector Efficiency: Challenges by. OECD Journal on Budgeting, 7(1), $1-42$.

[9] Dhludhlu, S., \& Lombard, A. (2017). Challenges of statutory social workers in linking foster care services with socio-economic development programmes Social Work / Maatskaplike Werk Vol 53 No 2 ; Issue 2. Social Work/Maatskaplike Werk, 53(2), 44-56. https://doi.org/10.15270/52-2-564

[10] Douglin, D. T., Knapp, C., Maynard, K., Manikas, P., \& Sheckler, A. (2015). Rebuilding Postwar Rwanda. Center for Development and Evaluation, 17(76).

[11] Gervais, M. (2013). Human Security and Reconstruction Efforts in Rwanda : Impact on the Lives of Women: Taylor \& Francis, Ltd . on behalf of Oxfam GB Stable URL: https://www.jstor.org/stable/4029942 of women. Development in Practice, 13(5), 542-551.

[12] Holmes, G. (2016). Gendering the Rwanda Defence Force : A Critical Assessment Gendering the RwandaDefence Force : A Critical Assessment. Journal of Intervention and Statebuilding, 8(4), 321-333. https://doi.org/10.1080/17502977.2014.964449

[13] Ifeanyi-obi, C. C. (2014). Socio-Economic Factors Affecting Choice Of Livelihood Activities Among Rural Dwellers In Southeast Nigeria So cio Economic Factors Affecting Choice Of Livelihood Activities Among Rural Dwellers In Southeast Nigeria. Journal of Agriculture and Veterinary Science, 7(4), 52-56.https://doi.org/10.9790/2380-07415256

[14] Kabananukye. (2016). Challenges for Pro-Poor Growth in Ugan da (Is sue June).

[15] Kanagawa, Makoto, T. N. (2018). Assessment of access to electricity and the socio-economic impacts in rural areas of developing countries Assessment of access to electricity and the socio-economic impacts in rural areas of developing countries. Energy Policy, 36(1), 2016-2029. https://doi.org/10.1016/j.enpol.2008.01.041

[16] Karaburun-sazani, M. (2012). Improving Coverage and Management Effectiveness of Marine and Coastal Protected Areas. Socio-Economic Study. December.

[17] Khisa, M. (2015). Political uncertainty and its impact on social service delivery in Uganda. Africa Development, 40(4), 159-188.

[18] Lwelamira, J. (2015). Grapevine Farming and its Contribution to Household income and Welfare among Smallholder Farmers in Dodoma Urban District, Tanzania. American Journal of Agriculture and Forestry, 3(3), 73 https://doi.org/10.11648/j.ajaf.20150303.12

[19] Malina, M. A., Nrreklit, H. S. O., \& Selto, F. H. (2011). Lessons learned: Advantages and disadvantages of mixed method research. Qualitative Research in Accounting and Management, 8(1), 59-71. https://doi.org/10.1 108/11766091111124702

[20] Matei, A., \& Dorobantu, A. D. (2015). Social Economy - Added Value for Local Development and Social Cohesion. Procedia Economics and Finance, 26(15), 490 - 494. https://doi.org/10.1016/s2212-5671(15)00878-3

[21] Martin, G., \& Kruger, A. (2020). Rwanda Defence Force. Defenceweb.Co.Za. https://www.defenceweb.co.za/security/africanmilitaries/rwanda-defence-force/

[22] Mohajan, H. K. (2017). Two Criteria for Good Measurements in Research: Validity and Reliability. Annals of Spiru Haret University. Economic Series, 17(4), 59—82. https://doi.org/10.26458/1746

[23] Munoz, C. A., Coleman, G. J., Hemsworth, P. H., Campbell, A. J. D., \& Doyle, R. E. (2019). Positive attitudes, positive outcomes: The relationship between farmer attitudes, management behaviour and sheep welfare. PLoS ONE, 14(7), 1-18. https://doi.org/10.1371/journal.pone.0220455

[24] Nkundabose, J. P., Ingabire, T., Nshimiyimana, E., Jacques, J., \& Niyotwizera, Y. (2020). Analysis of Current Environmental Impact Assessment System in Rwanda. July. https://doi.org/10.13189/eee.2020.070301 
[25] Paradowska, M. (2017). Measuring socio-economic welfare and sustainable transport - selected dilemmas. Ekonomia i Środowisko, 1`(5), 19-27.

[26] Pinder, C., \& Wood, D. (2012). Socio-economic Impact of Commercial Agriculture on Rural Poor and other Vulnerable Groups. A Working Paper. Department For International Development — Zambia, 2(12), 123.

[27] RDF. (2018).APPROVED_RDF_BOOKLET_Compressed.Bed Rock of national transformtion pdf (p. 56).

[28] Regnault, A., Willgoss, T., \& Barbic, S. (2018). Towards the use of mixed methods inquiry as best practice in health outcomes resear $\mathrm{ch}$. Journal of Patient-Reported Outcomes, 2, 2-5. https://doi.org/10.1186/s 41687-018 0043-8

[29] Riches, G. (2016). Hunger, Food Security and Welfare Policies : Issues and Debates in First World Societies. April 1997. https://doi.org/10.1079/PNS19970010

[30] Runfola, D., Batra, G., Anand, A., Way, A., \& Goodman, S. (2020). Exploring the socioeconomic co-benefits of global environm ent facility projects in Uganda using a Quasi-experimental Geospatial Inter polation (QGI) approach. Sustainability (Switzerland), 12(8), 1-13. https://doi.org/10.3390/SU12083225

[31] Saeed, B. I. I., Yawson, A. E., Nguah, S., Agyei-baffour, P., Emmanuel, N., $\&$ Ayesu, E. (2016). Effect of socio-economic factors in utilization of different healthcare services among older adult men and women in Ghan a. BMC Health Services Research, 16(390), 1-9. https://doi.org/10.1186/s12913-016-1661-6

[32] Sayinzoga, F., \& Bijlmakers,L. (2016). Drivers of improved health s ector performance in Rwanda: a qualitative view from within. BMC Health Services Research, 6(1), 1-11.https://doi.org/10.1186/s12913-016-1351-4

[33] Schüler, D., Brunn, C., Gsell, M., \& Manhart, A. (2016). Outlining So cioEconomic Challenges in the Non-Fuel Mining Sector Strategic Dialogue on Sustainable Raw Materials for Europe. Strategic Dialogue on Su stainab le Raw Materials for Europe, 9(05), 13.www.STRADEproject.eu

[34] Skuflic, L. (2016). Road Infrastructure and Regional Develo pment: 46 th Congress of the European Regional Science Association Volos, Greece, 09, 37.

[35] Strachan, A. L. (2017). Changes in economic activity during and after conflict. Helpdesk Report, 67(12).
[36] Semazzi, J. B., \& Kakungulu, M. (2020). Household determinants of fo od security in rural Central Uganda. 16(9), 1245-1252. https://doi.org/10.5897/AJAR2020.14992

[37] Stadler-altmann, U. (2020). Learning Environment: The Influence of School and Classroom Space on CHAPTER 23 Learning environment: The influence of school and classroom space on education. School of Economics, 2(8), 45-51.

[38] Stern, D. I., Burke,P. J., \& Bruns, S. B. (2017). The Impact of Electricity on Economic Development: A Macroeconomic Perspective David I . Stern , Paul J . Burke and Stephan B . Bruns EEG State-of-Knowledge Paper Ser ies Oxford Policy Management Center for Effective Global Action. Energy and Econoomic Growth, 1(6), 45-56.

[39] Tremblay, C. (2011). Advancing the social economy for socio-e co nom ic development: International perspectives. In Can adian Social Ec on omy Reasearch Partnerships (Issue http://140.230.24.101:8080/xmlui/handle/10587/570

[40] UNHCR. (2019). Protection of economic, social and cultural rights in conflict.

[41] Upreti, B. (2017). Contributions of Community Forestry in Ru ral Social Transformation: Some. Journal of Forestry and Livelihoods, 1(1), 31-34.

[42] Williams, T. P. (2018). The Political Economy of Primary Education : Lessons from Rwanda The Political Economy of Primary Education : Lessons from Rwanda. World Development, 96(April), 550-561. https://doi.org/10.1016/j.worlddev.2017.03.037

[43] Wild, L., King, M., Chambers, V., \& Harris, D. (2012). Common constraints and incentive problems in service delivery. ODI Working Paper, 3(351), 1 - 41. http://www.odi.org.uk/resources/docs/7791.pdf

[44] Wierzbicki, A. P. (2014). Socio-Economic Challenges from and for Future Internet. 3(1), 34-45.

\section{AUTHORS}

First Author - Manzi Isaac, Department of international relations, Mount Kenya University 